IJAMSR 3 (2) www.ijamsr.com CrossRef: https://doi.org/10.31426/ijamsr.2020.3.2.3113

\title{
IMPLEMENTATION OF INFRASTRUCTURE MANAGEMENT FUNCTION IN TEACHING AND LEARNING ART OF NON-FORMAL SCHOOLS
}

\section{Taufan Amirullah Abiyoga1, Mulyanto ${ }^{2}$, Edy Tri Sulistyo ${ }^{3}$}

${ }^{1,2,3}$ Master of Art Education, Post-Graduate Faculty, Universitas Sebelas Maret, Surakarta, Indonesia

E-mail: Taufanabiyoga04@gmail.com

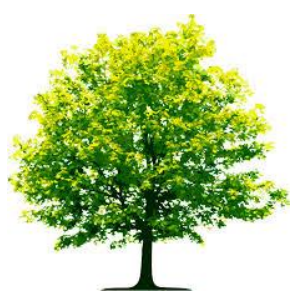

Keywords: Management, Infrastructure, Arts Learning

\section{A B S T R A C T}

School management is the activity of maintaining the potential that exists within the scope and sequence of the school held in a systematic way to achieve an educational goal. School management has an important role in educational institutions, both formal and non-formal towards the quality of learning, especially for art teaching and learning. Infrastructure management is one of the important aspects in the success of art learning. The purpose of this study was to determine the implementation of the infrastructure management function in the implementation of art learning in Eko Nugroho Art Class Yogyakarta. The focus of this research is to identify the implementation of the infrastructure management function in the study of art based on several parameters: planning, procurement, inventory, storage, maintenance, and elimination of school infrastructure. This research method uses a descriptive qualitative approach with data collecting sources of informants, events or activities, documents, and archives of Eko Nugroho Art Class Yogyakarta. The results of this study are the implementation of the management function of the art learning facilities and infrastructure as described. The implementation of school facilities and infrastructure management has been conducted in a very good and structured way.

Citation: Taufan Amirullah Abiyoga, Mulyanto, Edy Tri Sulistyo (2020). Implementation Of Infrastructure Management Function In Teaching And Learning Art Of Non-Formal Schools: International Journal of Advanced Multidisciplinary Scientific Research (IJAMSR) ISSN:2581-4281, 3 (2), February, 2020, pp $26-38$ 
IJAMSR 3 (2) www.ijamsr.com CrossRef: https://doi.org/10.31426/ijamsr.2020.3.2.3113

\section{Introduction}

Art education has a significant role in developing the intelligence of the nation's next generation. Art can be positioned as a tool in the implementation of education to prepare students to welcome independent life to come. The function and role in art education has its own place in each individual student in communicating the results of his creativity. In other words, art education is not just about the acquisition of values in the form of high numbers in a learning process, but rather on the formation of identity to achieve happiness in the future of individuals.

Art education is basically a place for students to develop skills through art as a medium of learning. The art program in formal and nonformal schools are an effort in realizing the success of art education in Indonesia. Art is a medium to increase knowledge, social awareness, and a fulfilment of cultural-based life needs. The success rate of art education in school education institutions is seen from the achievements obtained through the ability of good school management.
School management is the most important parameter in organizing, education and learning in formal and non-formal schools. Good school management can be obtained from the level of school success in realizing educational goals. In the implementation of school management, schools are required to always improve the quality and gather information sources, as well as to innovate more through the application of exploration of creative ideas to develop learning strategies that keep pace with the changing times. According to Mulyasa (2011: 12), to fulfil these interests, various learning resources for teachers and principals are needed in developing effective, efficient, independent, productive, and accountable schools.

Management of facilities and infrastructure is a system that is able to provide support to the success of a school in order to achieve educational goals as arranged at the beginning of term. Management of educational facilities and infrastructure can be interpreted as a process of cooperation in the efficient and efficient utilization of all educational facilities and infrastructure (Bafadal, 2008: 2). 
IJAMSR 3 (2) www.ijamsr.com CrossRef: https://doi.org/10.31426/ijamsr.2020.3.2.3113

The intention of this study was to determine the implementation of the management of school facilities and infrastructure function in the process of teaching and learning art at Eko Nugroho Art Class Yogyakarta. Infrastructure management in art teaching and learning is the most important thing in the continuity of the learning process as learning of art is basically conducted on practical activities. To resume, the management of school facilities and infrastructure is able to be the key to the success of the school in realizing the vision and mission of the school.

Based on research background, this article will identify the implementation of facilities and infrastructure management function in the process of teaching and learning art, especially in non-formal schools, based on several parameters: planning, procurement, inventory, storage, maintenance, and elimination of school infrastructure. Based on these problems, we were interested in researching with the title "Implementation of Infrastructure Management Function in Teaching and Learning Art in NonFormal Schools" to find out the existed management profile.

\section{Methods and Materials:}

This research was conducted on the selected non-formal school in Yogyakarta. The nonformal school was Eko Nugroho Art Class. The school was located on Jalan Poncowala, Kragilan, RT 01/RW 08, Sinduadi, Mlati, Sleman, Yogyakarta, Indonesia. This research method used a descriptive qualitative approach. Data collecting was done using observation techniques, interview techniques, and document / archive review (Moleong, 2014: 9). The descriptive qualitative approach was used in this study because it was adjusted to the material and research problem to be studied.

This research focused on the process of implementing the management of facilities and infrastructure in the Eko Nugroho Art Class Yogyakarta non-formal school. The data sources of this research were informants, events or activities, documents and archives of Eko Nugroho Art Class Yogyakarta. The instruments used in the study came from school personal data, archives, and documents. The research data included all school activities / agenda in the implementation of the infrastructure management function of art school. A data analysis technique was done using an interactive model of qualitative 
approach. Data analysis included data reduction, data presentation, drawing conclusions and verification. The validity of the data of this study used the technique of triangulation of sources and informative reviews.

\section{Results and Discussion:}

Infrastructure management is one of the parts that are highly considered by Eko Nugroho Art Class in all aspects relating to the teaching and learning of the arts. The results of the study are description of observations and field notes in the form of all activities and activities in the implementation of facilities and infrastructure management functions which include, planning, procurement, inventory, storage, maintenance, and elimination of school infrastructure in Eko Nugroho Art Class.

The results of an interview with the Director of Eko Nugroho Art Class explained that the main purpose of Eko Nugroho Art Class is to provide facilities for students who want to study arts outside of school's formal education to develop their talents and potential in art. The facilities provided by Eko Nugroho Art Class are able to meet the needs of students in the stages of learning the fine art into several classes that have different levels based on students' abilities. The management of facilities and infrastructure implemented at Eko Nugroho Art Class is under the auspices of the Eko Nugroho Foundation Yogyakarta, Indonesia. Eko Nugroho Art Class school management is the responsibility of the Director of Eko Nugroho Art Class. The implementation of school management functions has met the parameters of the infrastructure management function at Eko Nugroho Art Class, including planning activities, procurement of facilities and infrastructure, inventory of goods / assets, storage, maintenance, and elimination of school infrastructure. The school personnel have their respective job description related to school infrastructure management and almost all school personnel are concurrently given with more than one job.

The results of interviews with teaching staff at Eko Nugroho Art Class explained that all teaching staff and school employees in Eko Nugroho Art Class had an important role in implementing school infrastructure management, because teaching staff and school staff went directly to the field and were always involved with facilities and school infrastructure under the supervision of the 
IJAMSR 3 (2) www.ijamsr.com CrossRef: https://doi.org/10.31426/ijamsr.2020.3.2.3113

Director Eko Nugroho Art Class. Each school personnel has key of job description such as directors, teaching staff coordinators, teaching staff, marketing staff, financial administration staff and security staff. There are also additional job description beyond the main job description such as the procurement team, the warehouse coordinator, and the class coordinator. The Director appoints all team formation beyond the main job description in the management of school infrastructure at Eko Nugroho Art Class.

Implementation of Infrastructure Management Function in Teaching and Learning Art at Eko Nugroho Art Class

\section{Infrastructure Planning}

School facilities and infrastructure management planning is the whole process of estimating thoroughly based on the design of purchasing, procurement, maintenance, storage, distribution or manufacturing of equipment and equipment in accordance with needs analysis (Yuliana and Arikunto, 2008: 278). Facilities and infrastructure planning activities in Eko Nugroho Art Class are carried out at monthly meetings of the personnel. These agendas are held routinely every one month on Friday at the first week and additional situational meetings. During the meeting, a planning analysis was conducted on the development of Art Class. Art Class needs analysis and evaluation activities led by Director Eko Nugroho Art Class to discuss about the planning for the month ahead.

Based on the results of interviews with the Director Eko Nugroho Art Class, it was explained that the analysis of the planning of school facilities and infrastructure needed to be followed by all school personnel who were divided into 3 divisions, namely Teaching Staff, Administrative Staff, and Marketing Staff. Each division presented the progress and needs of the division, which included submission of the budget, analysis of the availability of equipment and supplies, as well as evaluation of learning activities and events.
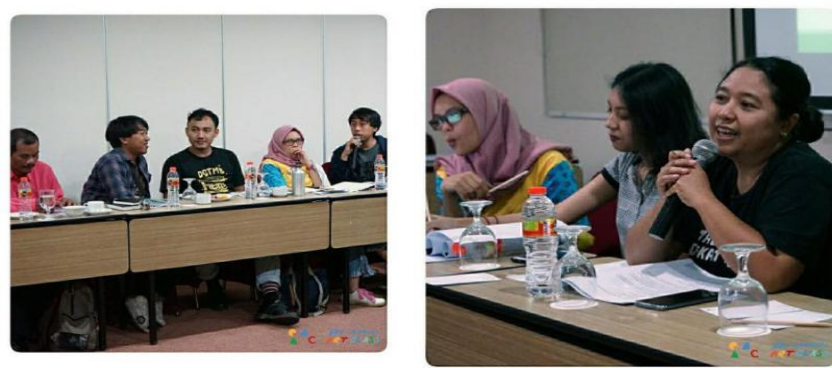

jFigure 1. Monthly meeting and discussion activities

Source: Document of Eko Nugroho Art Class 
Eko Nugroho Art Class facilities and infrastructure that need planning were divided into 2 types, namely moving and immovable objects planning. The planning activities of art learning infrastructure in Eko Nugroho Art Class categories of movable objects include: (1) analysis of the need for learning tools and materials by teaching staff; (2) teaching staff make a list of the needs for art tools and learning materials submitted to the teaching staff coordinator; and (3) the teaching staff coordinator prepared a budget plan (RAB) and it was presented at the meeting. Then it was submitted to the Director for approval.

The planning activities for art facilities and infrastructure, learning needed in Eko Nugroho Art Class were the responsibility of the teaching staff. In the process, the teaching staff regularly and periodically checked the availability of consumable learning tools and materials as well as the condition of equipment that was starting to break down and need new replacement. The activity was the basis for the preparation of the proposed budget plan every month.

The planning for facilities and infrastructure were also needed for immovable goods based on the results of research conducted in Eko
Nugroho Art Class. It was carried out by all school personnel and involves the Owner of the Eko Nugroho Art Class Foundation. The needs of this infrastructure include land / surroundings, access roads and buildings. The infrastructure procurement planning activities involved the Head of the Eko Nugroho Foundation because most of the procurement funds came from the Eko Nugroho Foundation. The flowchart of planning included an analysis of infrastructure needs, submission of a budget plan for the Foundation Management, awaiting the approval process from the Foundation Management and procurement.

\section{Procurement of Facilities and Infrastructure}

The activity of procuring educational infrastructure is obtained through purchasing activities, making their own, for the use of stacking and grants as an effort to expedite the process of education and learning (Yuliana and Arikunto, 2008: 278). Procurement is an activity in order to provide all the facilities and infrastructure needs that are used to achieve school goals. Procurement of facilities and infrastructure is the first operational function in the management of school education facilities and infrastructure. 
IJAMSR 3 (2) www.ijamsr.com CrossRef: https://doi.org/10.31426/ijamsr.2020.3.2.3113

Based on the results of an interview with the Director Eko Nugroho Art Class explained that the Team responsible for procuring learning facilities was the teaching staff / teacher, because the teacher played an active role in the condition of the infrastructure associated with learning art in the classroom. The teaching staffs know what needs to be prepared in the implementation of learning based on the lesson plan (RPP) that has been prepared based on classes / levels preserved by Eko Nugroho Art Class.

The Director of Eko Nugroho Art Class appointed a teaching staff coordinator to share additional teaching staff work description in relation to the provision of school infrastructure. The flow of art learning infrastructure procurement in Eko Nugroho Art Class through: (1) teaching staff appointed as the Infrastructure Procurement Team to analyze the needs of goods; (2) submits a budget plan (RAB) to the Director; (3) waiting for the Directors' approval; (4) disbursement of expenditure funds by the Financial Administration Staff; and (5) the procurement of goods by the teaching staff.
Based on the analysis of document review of the standardization of inventory of art learning infrastructure facilities in Eko Nugroho Art Class, it is shown that the way to procure goods for art learning needs is obtained by buying, grants from the Eko Nugroho Foundation and making their own. Purchases made by schools are handled by the school itself and do not involve other parties. The teaching staff coordinator Eko Nugroho Art Class explained that the school had not cooperated with the second party / partner related to the provision of learning infrastructure. Eko Nugroho Art Class realizes that the capacity of learning infrastructure needs that can still be done independently without any partnership with suppliers to meet the needs of art learning infrastructure.

The purchase of learning equipment and equipment independently is carried out by the teaching staff responsible for the procurement team, while the procurement of immovable property such as tangible infrastructure in the building is handled by the Eko Nugroho Foundation. 
IJAMSR 3 (2) www.ijamsr.com CrossRef: https://doi.org/10.31426/ijamsr.2020.3.2.3113

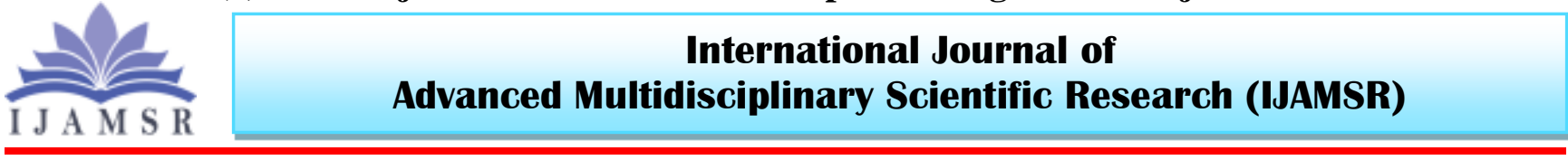

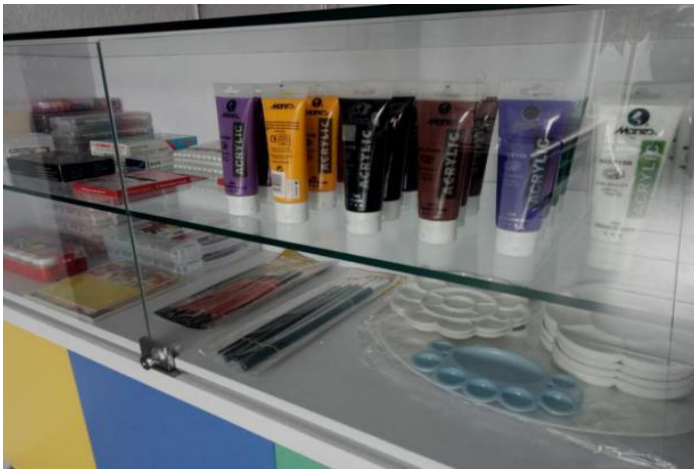

Figure 2. Procurement of tools and materials for fine arts learning

Source: Document of Eko Nugroho Art Class

In addition to the purchase method, the school also fulfils the needs of the procurement of goods by making their own. This is done in order to minimize the funds that must be spent. As for some needs that can be made such as teaching aids, interactive learning media, and others to the needs of art exhibitions. The purchase process has been done in the beginning of term.
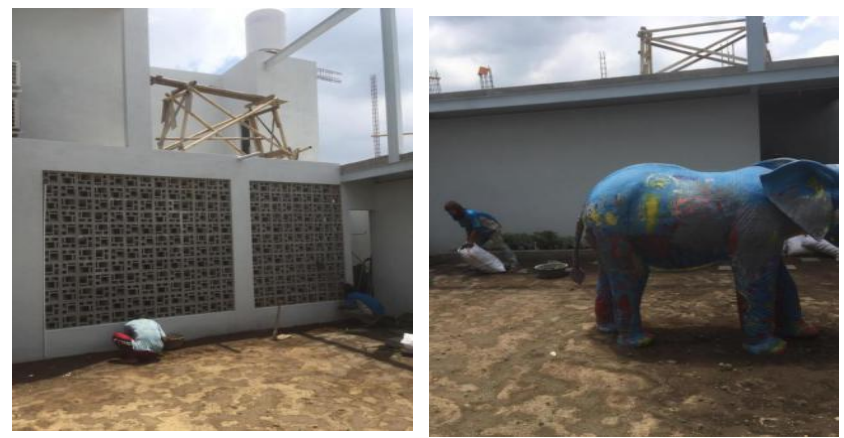

Figure 3. School infrastructure development activities

Source: Document of Eko Nugroho Art Class

\section{Inventory of Goods / Assets}

Inventory is an activity of recording goods carried out in an orderly and systematic manner for the purposes of handling and recording using administrative instruments such as goods receipt books, good purchase book, inventory master book, inventory class book, stock book, and other books.

Inventory of school infrastructure facilities in the Eko Nugroho Art Class has been running routinely, but the inventory system of facilities and infrastructure has not been given much attention. The system of recording goods / assets of schools are not as comprehensive as recording the ledger, inventory and it has been done based on common consideration Recording is only based on the condition, condition and quantity of goods using a checklist of items in an item inventory card and room inventory card Inventory / recording system of goods entering and leaving the warehouse space has also not been implemented properly.

Director Eko Nugroho Art Class explained that the recording system for school facilities and infrastructure is still very simple, because the school does not involve many parties related to 
IJAMSR 3 (2) www.ijamsr.com CrossRef: https://doi.org/10.31426/ijamsr.2020.3.2.3113

\section{International Journal of Advanced Multidisciplinary Scientific Research (IJAMSR)}

the administrative matters of recording, inventory recording is carried out as simple as possible for all.

In general, all school affairs related to the administration and recording of goods are additional job description that is charged by holders of needs, such as teaching staff responsible for recording learning facilities, marketing staff responsible for recording event and promotional items and administrative staff responsible for inventory of goods related to office needs.

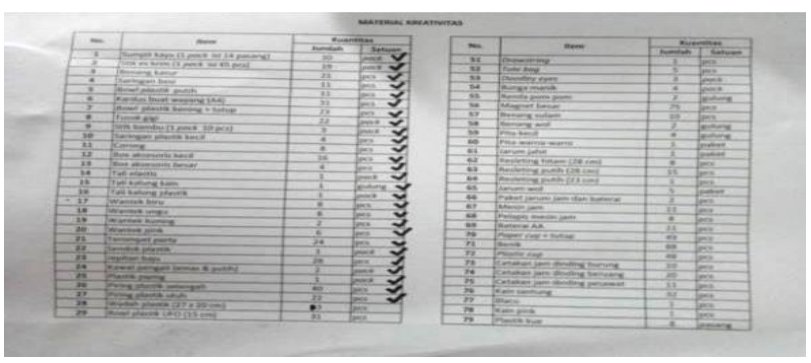

Figure 5. Inventory cards in storage room Source: Document of Eko Nugroho Art Class

\section{Infrastructure Storage}

Storage is an activity of storing educational infrastructure in a place so that the quality and quantity is guaranteed (Barnawi, 2012: 73). In general, the function of a school infrastructure facility storage activity is to coordinate the receipt of goods, storage, and activities to release the goods.
Eko Nugroho Art Class has one equipment storage room or warehouse to accommodate all items related to art learning equipment and equipment, art events, furniture and office equipment, and exhibition properties. Spacious warehouse area of $6 \mathrm{~m} 2$, the size is too small for a school storage warehouse. Storage systems in school warehouses are grouped by type of goods and their categories. There are items for learning needs such as paint supplies, painting brushes, glue, practice equipment, and others were in each category applied. There is an inventory card containing a list of available items. The warehouse does not have a good inventory system such as recording goods entry and borrowing.

The warehouse or storage room category in Eko Nugroho Art Class is a central warehouse, because all items for learning, event,marketing, promotionn and exhibition needs are stored in 1 central school storage room or warehouse.

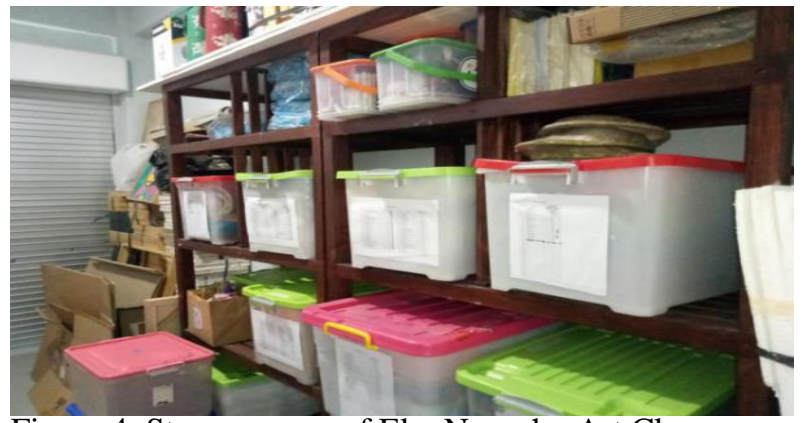

Figure 4. Storage room of Eko Nugroho Art Class Source: Document of Eko Nugroho Art Class 


\section{Infrastructure Maintenance}

According to the Directorate of Education Personnel of the Ministry of National Education (2007: 31), "maintenance of educational infrastructure is an activity to carry out arrangements and arrangements so that all infrastructure facilities are always in good condition and ready to be used efficiently and successfully in achieving educational goals". Therefore, care needs to be taken to avoid and minimize the nuisance or destructive elements. Maintenance activities, especially in school infrastructure, based on the results of the questionnaire were distributed to teaching staff respondents. All of respondents were $100 \%$ teaching staff playing an active role in maintaining school infrastructure. Teaching staff also instills understanding for students to maintain and manage school infrastructure since the beginning of term.

Maintenance is divided into 2 namely maintenance in the classroom and outside the classroom. All teaching staff are responsible for the maintenance of goods, equipment and learning equipment in the classroom and storage warehouse, while maintenance outside the classroom is the responsibility of the office boy and all school personnel, including teaching staff, marketing staff, administrative staff and supervised by the Director Eko Nugroho Art Class.

School hygiene and safety factors are also highly considered by schools, this is evidenced by the condition of the school, which is always clean and there are several trash cans and cleaning equipment that are at several points within the school. The activity of maintaining school facilities and infrastructure at Eko Nugroho Art Class runs very orderly and very well and produces a very comfortable learning atmosphere in every school environment. The school also collaborates with the Public Works Office (DPU) to distribute the waste generated every day in order to maintain the cleanliness of the school.

\section{Infrastructure Elimination}

Elimination of facilities from the inventory list serves to prevent or reduce greater losses, reduce waste of costs, ease the workload of inventory and free up organizational unit responsibilities for an item or educational facility (Yuliana and Arikunto, 2008). Elimination can be through sale, exchange of goods, gift or burnt. 
IJAMSR 3 (2) www.ijamsr.com CrossRef: https://doi.org/10.31426/ijamsr.2020.3.2.3113

Based on the results of research in Eko Nugroho Art Class, the procedure for removing infrastructure is not as complicated as that done by formal schools. The activity of removing facilities is categorized into two, namely the removal of movable property and the removal of immovable property. The movable goods category includes office equipment, office equipment, visual arts learning tools and materials, tables, chairs, furniture, trash bins, and others. While the category of immovable property includes buildings, access roads, parking lots, prayer rooms, canteens, shops, parks, galleries and others. These need to be taken care too.

The procedure for removing the movable property category is carried out by the person in charge of the division involved and then submits an application to the Director for approval and will be followed up. The highest decision related to this is the Director of Eko Nugroho Art Class. Movable property included in the deletion list includes the following criteria: (1) the goods are heavily damaged and difficult to repair; (2) goods damaged naturally due to use; and (3) functions are no longer needed and are not able to meet current needs.
Whereas the procedure for the removal of immovable property is carried out by the school through the Director to submit a proposal for the removal of infrastructure to the Eko Nugroho Foundation, then for a visitation and approval for the removal process. The highest decision in this regard is the Owner of the Eko Nugroho Foundation.

The removal of facilities and infrastructure in Eko Nugroho Art Class is entirely through fairly simple procedures without involving many parties or agencies, so that they can run quickly and smoothly.

\section{Conclusion:}

The implementation of facilities and infrastructure management function in nonformal school institution Eko Nugroho Art Class has met the requirement parameters, namely planning, procurement, inventory, storage, maintenance, and elimination. Eko Nugroho Art Class is basically a non-formal school in the field of art education that has progressed very rapidly since the beginning of their first year in 2015. This is inseparable from the school management implemented therein, especially the management of fine arts learning infrastructure. Based on these results, it can be 
concluded to several important points as follows:

1. The implementation of the planning function is very good because all planning activities always involve all parties in the school personnel, so that the planning of infrastructure can run optimally.

2. The implementation of the procurement function is quite good because the directors' act of giving a double job description to teaching staff in the procurement of learning infrastructure is very well targeted to minimize the wasting of funds for needs that are not on target.

3. Implementation of the inventory function still needs a lot of attention and improvement. The warehouse inventory system has not used a standard inventory system according to national standard procedures. This is proven because there is no record in the inventory book.

4. The storage function implementation is quite good. The school has an ideal warehouse to accommodate all school needs. Weaknesses in the storage system is that there is no staff who is fully responsible for the activities in and out of the recording of goods in the storage warehouse, it can have a bad impact if there are errors in the collection of goods.
5. Implementation of the maintenance function is very good. The school always maintains and maintains all facilities, both in the classroom and outside the classroom. The teaching staff also gives direction to students to jointly maintain all infrastructures related to learning and outside learning. This is evidenced in the condition of the school environment which is very clean, neat, disciplined, and in good condition.

6. Implementation of the function of eliminating infrastructure is divided into 2 namely the removal of movable and immovable property. The removal of movable property has a fairly simple procedure because it is under the decision of the Director of the school, but for the removal of immovable property involves the Owner of Eko Nugroho Foundation through the procedure for submitting a proposal for removal, visitation, approval and action.

\section{Acknowledgments:}

We would like to give gratitude and appreciation to the editorial board and reviewers of the International Journal of Advanced Multidisciplinary Scientific Research (IJAMSR). We also want to 
IJAMSR 3 (2) www.ijamsr.com CrossRef: https://doi.org/10.31426/ijamsr.2020.3.2.3113

acknowledge:

1) Universitas Sebelas Maret Surakarta, Indonesia

2) Head of Art Education Master Program, Prof. Dr. Mulyanto, M.Pd.

3) Supervisor 1 Prof. Dr. Mulyanto, M.Pd.

4) Supervisor 2 Dr. Edy Tri Sulistyo, M.Pd.

5) Director of Eko Nugroho Art Class Yogyakarta, Ratri Kartika Sari, S.Pd., M.B.A.

6) Staffs and employees of Eko Nugroho Art Class Yogyakarta

7) Students of Eko Nugroho Art Class Yogyakarta

\section{References:}

[1] Bafadal, I. 2008. Manajemen Perlengkapan Sekolah, Tiori dan Aplikasi. Cet.III, Jakarta: Bumi Aksara.

[2] Barnawi. 2012. Manajemen Sarana dan Prasarana Sekolah

[3]Moleong, J.L. 2014. Metodologi Penelitian Kualitatif. Bandung: PT. Remaja Rosdakarya.

[4] Mulyasa, E. 2011. Manajemen Pendidikan Karakter. Jakarta: Bumi Aksara.

[5] Yuliana, L. \& Arikunto, S. 2008. Manajemen Pendidikan. Yogyakarta: Aditya Media Yogyakarta. 